\title{
TRENDS AND PERSPECTIVES ON ENTREPRENEURIAL EDUCATION IN ROMANIA AND THE EU
}

\author{
Casiana ILLE \\ Doctoral School of Economics, Faculty of Economic Sciences, University of \\ Oradea, Oradea, Romania \\ casiana.ille@gmail.com
}

\begin{abstract}
Entrepreneurial education (EE) has been a blossoming subject over the past years especially due to its importance and relevance to the economy both regionally and globally. The academic world still needs to conduct sustained research on the topic in order to fully throw a light on the importance that EE has on the society and its decisive role in transforming it. Economic, financial and EE has gained new dimensions lately, with an important raise of the focus both in theory and practice. This research studies the need for EE and financial literacy. In Europe, recent surveys show that young people acknowledge their lack of knowledge regarding entrepreneurship and state that schools should help them have an entrepreneurial mindset and know more about finances. In today's dynamic environment and especially after the covid-19 crisis, the need on the workplace has changed and the skills that can be acquired through entrepreneurship and financial training and acknowledged by scholars, population, businesspeople and media as vital for the way things work in today's economy. Teaching individuals how to think entrepreneurial becomes even more important in times of crises, or in a dynamic environment, where creativity, adaptability and innovation are key for survival. Key trends and developments are analyzed and the actors involved in shaping and raising awareness regarding financial illiteracy and the need for $E E$.

This paper combines literature review methods and it also develops a conceptual debate around the research conducted in the field of EE with the purpose of contouring a consolidated methodological approach based on the so-far experience linked with today's challenges. Due to the fact that EE is now one of the fastest growing research subjects in the world, an important emphasis has to be placed on the comprehension of the connection between business management practices and the academic theory, as research has previously indicated. The outcome of this analysis aims to throw more light to understanding the evolution EE has had and provides an overview of the relevant trends in the field.
\end{abstract}

Keywords: education; entrepreneurship.

JEL Classification: I25; L26.

\section{Introduction}

The existing literature on $\mathrm{EE}(\mathrm{EE})$ is rich and complex and it addresses the nature, motivations and predictors, entrepreneurial traits, influence of the economic environment, policies to foster and enhance its effectiveness etc. (Badulescu \& Badulescu, 2014) and the information regarding entrepreneurship is consistent, 
diverse but unsystematic and contradictory even if it is referring to the entrepreneurial spirit, the motivations, specificities determined by gender, education, economic environment or personality (Badulescu \& Badulescu, 2013).

Studies that have implied seemingly experimental methods have acknowledged that EE will reveal shy effects or no effects on short-term results such as entrepreneurial intentions (Oosterbeek, et al., 2010) but might enhance noncognitive competences that are significant for entrepreneurship (Rosendahl Huber, et al., 2014). Even if empiric studies and analyses have found weak or no link between EE and the motivation of starting a business, it has been proved that the link between entrepreneurial performance and EE is quite important and that there is a positive relation between the two in terms of income, firm survival or growth and profits (van der Sluis, et al., 2008), (Unger, et al., 2011) (Van Praag, et al., 2013). The so-far findings displayed by the literature in regards to the effectiveness of $\mathrm{EE}$ leads to the conclusion that the success of EE approach consists of the theoretical relevance of practical curriculum (Elert, et al., 2015) because successful entrepreneurship is rather related to being faced with previous entrepreneurial experience than formal education (Dencker, et al., 2009), (Folta, et al., 2006), (McNally, et al., 2013), (Toft-Kehler, et al., 2014) and the acquisition and enhancement of the skills desired in entrepreneurship are more important and relevant for success rather than a degree (Lazear, 2004), (Wagner, 2003). The majority of the studies sought to measure the effect of EE on the development of entrepreneurial-enhancing assets such as knowledge, skills, intentions to launch a business or general positive perception regarding entrepreneurship mostly because these outcomes can be measured as indicators right after the completion of the educational program (Elert, et al., 2015).

$\mathrm{EE}$ is an important tool to be used in order to enhance regional development and it is important that the concerned actors cooperate toward reaching the same goal that benefits and strengthen the entrepreneurial intention of the society (Anderson, et al., 2017).

\section{Key trends and developments in European EE}

As EE has been historically an important engine for economic growth in the United States (OECD, 2008), Europe has the opportunity to learn from this experience and implement the appropriate measures to the old continent. A first important issue to be observed is that in the US, most of the leading 100 businesses are only 20-30 years old, while in Europe many of ones included in the top have been here for over 100 years and as Birch states in 2002, it is important for the vitality of an economy that old companies evolve or are replaced by more dynamic firms that renew the economy (Birch, 2002). In Europe, the focus on entrepreneurship only started to grow in the mid-1990s, while in the US the direction was given more than 50 years earlier (Twaalfhoven \& Wilson, 2004). An important difference between EE in Europe versus EE in the US is the definition and focus of entrepreneurship; in the US the focus is put on the growth-oriented companies, while in Europe entrepreneurship refers to nurturing SMEs which hold an important role in the European economy and there is even a kind of legacy as far as SMEs are concerned, most of them are family-owned. Wilson (2002) argues that just because a business is large, that doesn't make it less entrepreneurial 
than a smaller one and that studies after studies have shown that SMEs are not growth-oriented (OECD, 2008).

While SMEs play an important role in the European economy (99\%) there are 25 million European SMEs, one of their main challenges is that they still encounter several growth-stagnant issues. Only 600.000 SMEs export goods outside of the European Union, less than 2,5\% (European Commission, 2020). All companies have to be supported and encouraged even though the ones with the most impact on dynamism, innovation and competitivity are those that are growth-oriented. The issues identified almost ten years ago by the European Commission still persist nowadays and they are: the skills of young people, low exposure to entrepreneurship and the lack of role models, high administrative and financial complexity, the low focus on growth entrepreneurship and expansion and increased focus on the other hand on small and middle-sized enterprises (SMEs) (OECD, 2008). The focus has to shift from the old traditional educational purpose, to create good employees, to equipping the young people with an entrepreneurial mindset that will enable individuals to succeed in this dynamic environment and economies to nurture innovation, competitivity, and other entrepreneurial-driven tools for economic and societal development (OECD, 2008).

Recent studies still illustrate the same persisting issues that were identified ten years ago. Since the 2008 crisis, unemployment and financial insecurity continued to expand and when the economy was starting to be back on track, the global 2019 pandemic reset the status-quo and in Europe, unemployment rate was raised from 6.4\% in March 2020 to 8.1\% in March 2021 (Eurostat, 2021). As a solution to these issues, policy makers, academics and media stress out the role and importance of financial and EE into all levels of education. Ransome (2014) argues that "The working world has changed. A university education used to guarantee a long-term job in a large company. Not anymore. Today, large companies are disappearing. Employment opportunities are short-term. Most people in tomorrow's working world will find employment filling niche gaps, providing goods and services. People who are unprepared for that reality will be unable to provide for themselves. They will need to think like entrepreneurs" (Ransome, 2014).

The policy makers, theoreticians and others that support the implementation of financial and EE for everyone argue that this training would benefit in particular the individuals living in low-income communities due to the fact that this would secure and empower both the individuals and the communities financially (Arthur, et al., 2018). The literature regarding EE has exponentially grown in the past decades, but even so most of the research is directed towards business activities rather than educational pursuits (Ratten \& Jones, 2021) and this limits its applicability to other different contexts (Bechard \& Gregoire, 2002). Due to the fact that entrepreneurship should be taught in a practical way, educators should use innovative teaching techniques such as virtual reality or gaming, as Ratten \& Jones (2021) suggest.

Teaching entrepreneurship becomes even more important in times of crisis when special skills and attitudes are required in order to survive. The covid-19 crisis determined business ventures and business people that gathered to find solutions and EE is now needed more than ever due to its approach regarding creativity and positive thinking (Kraus, et al., 2020); entrepreneurship is needed in the society due to its role in creating societal development and keeping peace and its 
approach has to change now after this global crisis to a direction that takes into account the latest developments in the social and economic environment, the crisis management aspect and digital transformation in EE (Ratten \& Jones, 2021).

Financial education (FE) and economic education have been seen by many as a part of the EE and it does not only imply handing over financial information and knowledge, but also, developing better financial behavior and attitudes. A fundamental indicator of an individual's ability to take the most appropriate financial decision is the level of financial literacy. Nowadays, the focus that has been shifting from the traditional understanding of finance toward financial innovation, as the European Banking Authority (EBA) FE Report 2019-2020 has shown, setting a roadmap to digital financial literacy, crypto assets, cybersecurity and disclosure to customers via digital means. With more FinTech services, businesses improve their interaction with the customers with digitalized services that compete with the traditional finance methods. Financial empowerment is an essential tool for acquiring financial stability and in the European region (EBA Consumer Trends, 2019, fig. 1, p. 13). In order to increase financial literacy, schools, workplaces, NGOs, training firms, governments have various opportunities to shape the financial development of future consumers, citizens and employees because this will determine the overall financial development. display an effective FE, the initiatives taken have to be large and scalable (Lusardi, 2019). Latest studies suggest that an integrated approach regarding FE from a behavioral economics point of view could be a more appropriate approach, due to the fact that people's financial behavior (e.g.: excessive borrowing) is determined by multiple factors and only by researching those psychological, social, cultural aspects and others, the complexity of the issue can be understood and the behavioral biases taken into account, because behavioral sciences argue that being informed does not mean necessarily that individuals will make informed choices but on the contrary, consumer behaviors are sometimes incoherent and irrational (de Meza, et al., 2008), (Erta, et al., 2013). School-based education has an important role and can be transformational for young people (Lusardi, 2019) and well-planned education programs together with teacher education and high school FE requirements are linked to higher credit scores among young adults in the USA (Urban, et al., 2020) for OECD's Program for International Student Assessment (PISA). The latest Report shows that between 2012 and 2018 the mean performance in financial literacy did not change significantly, but there has been a 20 score points raise between 2015 and 2018 (from 476 to 496 points) but the highest level of proficiency in financial literacy, level 5 was still only attained by $10 \%$ of the students across OECD countries (OECD, 2020). The comparison between 2012 and 2018 shows significant changes only in the case of two countries out of the 9 with data from both years: Estonia, where the mean performance was improved by 18 score points and Australia, where it was lowered by 15 score points (OECD, 2020). The need of FE in college is also an important aspect not only for future entrepreneurs or managers that need to manage their enterprises' finance but also for individuals that need an increasingly complex knowledge to manage their own finances over the lifetime. Clark et al (2017) demonstrates that FE can be also delivered in the workplace, conducting a study regarding a targeted adult financial training program in 2013 with the employees of the US Federal Reserve System. The study concluded that the training led to 
significant changes in the financial planning and decision-making of the employees regarding retirement planning behavior and investment portfolios (Clark, et al., 2017). With regards to the delivery methods for FE targeting adults, it has been demonstrated that video formats have a higher impact than narration on shaping the financial behavior (Heinberg, et al., 2014). Training providing companies play an important role in disseminating financial knowledge and the role of private companies in mitigating financial literacy should be explored more. Due to the previously stated issue of financial illiteracy, FE should be also provided in the community, targeted to specific groups. There are numerous ways and places to creatively display FE and a contemporaneous example is given by the International Federation of Finance Museums (IFFM) that developed a framework for cooperation between museums to develop and implement innovative ideas to promote financial literacy globally (IFFM, 2021). Through initiatives like the these, museums engage old and young people in pursuing financial literacy.

Through their platforms and agendas, international organizations promote a standardization that can undermine states' authority and autonomy in setting targets and own local indicators (Rinne, 2008). The OECD Learning Compass 2030 incorporates a great deal of recommendations toward an interdisciplinary approach throughout different domains and emphasizes the inter-relatedness of knowledge, skills, attitudes and values that enable fair and sustainable economies with the need of creativity and innovation for the people to succeed in today's economic environment where non-routine cognitive skills such as creativity, social and emotional skills are vital (OECD, 2018). The emerging role of private actors and NGOs is not only shifting power, but also engaging a different discourse with regards to $\mathrm{EE}$. One of the most prominent international organizations that fosters EE is Junior Achievement, a non-profit (Elert, et al., 2015).

National states also play an important role in the development of entrepreneurship and financial literacy, yet their role is insufficiently explored in practice. The EU reports suggest that governments invest inadequately in their human resource and that they do not contribute enough in promoting EU's competitiveness (European Commission, 2012, p. 4). A year later, the European Commission releases a report that compares the top policies among countries in the EU regarding EE and the contributions of the member states towards EE, coming from different ministries (European Commission, 2013). The report highlights Denmark as the best example of a coherent policy with four ministries working together through a partnership managed by a private organization (Amiel, et al., 2021). This approach of "shaming" the under-performant European states with regards to EE involvement can be constructive, creating a certain competition among member states that could result in better defining, implementing and measuring EE.

\section{Entrepreneurship and FE in Romania}

Research has shown that participation in EE programs raises the probability of engaging in entrepreneurial activities by $35 \%$ on average a total of which 7 percentual points come only from the improved self-perceptions regarding their entrepreneurial skills by the participants (European Commission, 2019). In the EU is optional and only a handful of countries have made it compulsory. "On average, 
EU countries spend about one third of their public expenditure for education on pre-primary and primary education; $41 \%$ on secondary education; and $15 \%$ on tertiary education. Looking at different education sectors, real expenditure on secondary and post-secondary education decreased $(-1.3 \%$, between 2016 and 2017) and increased in pre-primary and primary education $(+1.4 \%)$, as well as tertiary education (+1.7\%)" (European Commission, 2019, p. 17). As far as Romania is concerned, the forementioned Report states that "public spending on education is low in EU comparison, while the sector's investment needs are high" (European Commission, 2019, p. 19). The recommendations are that additional funding is desirable and also better support for teachers to raise the quality of education through sustained professional development. As far as adult learning is concerned, the proportion is still low despite the demand for upskilling and reskilling.

Data included in the last Global Entrepreneurship Monitor (GEM) Report for Romania show that more than $42 \%$ of the established business owners have at least post-secondary education and more than half of the intentional entrepreneurs have a secondary degree. Young entrepreneurs therefore are inclined toward obtaining higher education in Romania, just like the established business owners and the higher rates of entrepreneurs that have graduate experience are among the young entrepreneurs. The National Experts Survey (NES) is a part of the Global Entrepreneurship Monitor (GEM) methodology and the main purpose of the survey is to assess the national context in which businesses start and operate. It assesses various entrepreneurial framework conditions and other topics related to entrepreneurship that help with a better understanding of business' creation and

growth. Due to the lack of harmonized national measures, NES is the only international comparable data that specifically addresses the environmental influence factors for businesses performance and it focuses solely on entrepreneurial framework conditions instead on general economic factors (EFC). Data collected from national experts selected on a basis of reputation and experience is encompassed on a Likert scale, where 1 means completely false and 5, 7 or 9 means completely true, according to the expert. The scoring scales have been extended to 9 points since 2015, but it started with a 1-5 scale that is still kept for comparability reasons. The questions are regarding entrepreneurial finance, government policy, government entrepreneurship programs, EE, R\&D transfer, commercial and legal infrastructure, entry regulations, physical infrastructure and cultural and social norms. With regards to EE in Romania, according to national experts, "the EE in primary and secondary school is ranked lower than in postsecondary, vocational, professional, college and university education in all analyzed countries from the efficiency-driven economies from the European Union in 2014" (Dezsi-Benyovski, et al., 2014, p. 41). The highest value given by national experts for the Romanian EE is for the question regarding if "Colleges and universities provide good and adequate preparation for starting up and growing new firms" showing relatively high level of confidence with regards to the ability of the Romanian universities to prepare young people to start and grow new companies, the highest score compared to the other countries included in the study, followed by Lithuania, while the lowest score was given for the Croatian colleges and universities. Even if compared to the other countries included in the study, Romanian EE is scored slightly higher, the rating is still not satisfying and 
display an important need for enhancing the quality of the EE provided at all levels. The need for raising the level and quality of the entrepreneurial and FE is not only in the hands of the public institutions The role of the society and culture in fostering an entrepreneurial mindset is an important indicator of the entrepreneurship levels in a certain country but it can be viewed also as an indicator of the level of EE provided. As far as cultural and social norms in the view of national experts are concerned, the summary of the study shows that Romania is not as supportive as a society for their entrepreneurs compared to Lithuania or Poland, but still shows more support than Hungary or Poland (GEM, 2014). The highest score was obtained at the following statement: "The national culture encourages creativity and innovativeness" (2.78); while the lowest when the issue in question was whether "The national culture encourages entrepreneurial risk-taking" (2.29). The statements were rated on a scale from 1-5 with 1 meaning "totally agree" and 5 "totally disagree". In order to raise awareness regarding the essential role and the positive effects of entrepreneurship on the societal welfare, EE plays a major role in modelling a society that welcomes and supports entrepreneurship.

While formal education plays a major role in equipping young people with entrepreneurial skills, there are non-governmental actors such as non-profit organizations like Junior Achievement Romania or Erasmus for Entrepreneurs, that play an important role EE and FE in partnership with the public educational system.

When it comes to financial literacy, the numbers are not optimistic, as a 2020 OECD report shows after a survey conducted between 2019-2020 with the purpose of assessing financial literacy. 26 countries were included in the study and 125.787 adults were interviewed. The results represent the sum of three elements (OECD, 2020): 1. Financial knowledge score (takes the range 0 to 7); Financial behavior score (takes the range 0 to 9); 3. Financial attitude score (takes the range 1 to 5 ).

The results show the scores out of the total of 21 points and the average scores are 12.7 for all countries and 13 for OECD members. Romania (11.2) is among the most financially illiterate countries in survey, together with Italy (11.1) and Colombia (11.2) while the most well-performing scores were achieved by Hong Kong (14.8), Slovenia (14.7) and Austria (14.4) (OECD, 2020). The report shows that even the highest scores that were achieved by adults in Hong Kong were still only at $71.1 \%$ of the total, which only suggests that a basic level of financial knowledge, some long-term healthy attitudes towards saving money and handling finances and general financial prudent behavior (OECD, 2020). Even if the score of Romania is low when compared to the reference 21 points, when compared to the average score, the difference is not high, with less than 2 score points below other countries, even developed economies such as Germany and 1.5 below average of all the surveyed countries, scoring nevertheless slightly higher than Italy. Compared to Moldova, Romania achieved lower scores in all three domains, knowledge, behavior and attitude and the lowest score was achieved by Romania in the area of financial knowledge. Knowledge can model behavior and attitude; therefore, a proper FE would raise the financial awareness and knowledge, which will therefore enhance the financial behavior and attitude.

The main organizations involved in Romanian FE are the commercial Banks, the Romanian Banking Associations, the NBR in partnership with the Ministry of 
Education, Bank Deposit Guarantee Fund and several NGO's (National Bank of Romania, 2015). The main target groups identified by the NBR are the pupils and students, teachers, banking/business communities, the academic management, the media and the public at large. The tools proposed by NBR in the spread of financial literacy for the target groups are seminars, public conferences, group visits, digital tools and written materials. There are several projects developed to raise financial literacy in Romania and the results are showing a growing positive outcome in terms of participants in the programs which are developed in partnership by private and public companies, together with several NGO's. More digital tools have to be developed in order to reach the young people and local projects should be implemented by creating private-public partnerships and enhanced cooperation with the entrepreneurship and FE providers. There are steps taken in the correct direction for setting a proper framework for EE and FE in Romania, starting with 2011 a new Law of Education was adopted with the purpose of modelling the Romanian educational system to today's labor market needs and economic, financial and EE are part of the reform process in Romanian education (Lacatus, 2016). Starting with the new educational law, FE was incorporated in the school curricula with one program approved for the middle school level and one at high school level. The recommendation is that all educational institutions that are interested in delivering FE should develop an optional program concerning financial issues.

\section{Conclusions}

EE is an important topic in the business world and it has been intensely researched the academic in field due to the fact that the literature has to provide a direction for the fast-changing world and businesses, states and organizations have tried to provide solutions and directions. GEM report 2019/2020 suggests that the directions needed for empowering aspiring entrepreneurs are "policy changes or educating more or educating differently" (p. 16). The international organizations that seek to raise awareness regarding financial illiteracy and the need for EE suggest that the challenge is to find the proper ways and the proper channels for promoting them. The main identified issues among young people are the skills of young people, low exposure to entrepreneurship and the lack of role models, high administrative and financial complexity, the low focus on growth entrepreneurship and expansion and increased focus on the other hand on SMEs (OECD, 2008).

The responsibility of the governments remains to create the proper implementation framework where NGO's, universities and private companies unite efforts to promote EE and financial literacy. As far as the methods are concerned, theoreticians advise that EE should be taught in a practical way, using innovative techniques and teaching should be focused on providing the students with an entrepreneurial mindset rather than the traditional approach that was focused on delivering good employees.

As far as Romania is concerned, the findings reveal a low level of financial literacy,

Romania being one of the least financially literate in the surveyed countries as OECD has shown in latest study but scoring slightly higher than Italy, close to Germany's score and just slightly below the average score of the surveyed 
countries with 1.5 score points below the average. Several authors argue that the role of the state in providing financial and $E E$ is debatable, due to the lack of transparency and due to the political aspect, where parties can divert funds and use them to their own interest. OECD and the EU have tried to raise awareness, conduct surveys to assess the need for training and provide the framework for the stakeholders to meet, exchange ideas and further implement them. In Europe there are discrepancies between countries and also between genders regarding financial literacy, even in the most developed European countries.

Several measures have been imposed by the Romanian state as a consequence of the international surveys, placing Romania among the most financially illiterate countries in the world and also due to the national experts' commission assessment, that revealed a mediocre approach toward economic, financial and EE. There are two courses that are taught at undergraduate level, one in middle school and one in high-school that aim at teaching young people basic financial knowledge. Nevertheless, there are several authors that argue the fact that state's involvement is debatable, taking into consideration lobby groups and powerful politicians.

In today's dynamic world, financial knowledge and an entrepreneurial mindset are vital for the future success of young people. Technology and digitalization have changed the economic environment as we know it and the financial empowerment of individuals is important for the development of society at large and for the avoidance of future crises. Collaboration between universities, schools, the private sector, governments and regional and international organizations can support the healthy development of EE and financial literacy and could be the key to formulating the best strategies and setting future directions.

\section{References:}

1. Anderson, G., Ferreirra, J. \& Marques, C. S., 2017. EE and training as facilitators of regional development: A systematic literature review. Journal of Small Business and Enterprise Development, Volume 25, pp. 17-40.

2. Badulescu, A. \& Badulescu, D., 2013. How Entrepreneurial are Doctoral Students? Some Evidence from Romania. Journal of Eastern Europe Research in Business \& Economics, Volume 2013.

3. Badulescu, D. \& Badulescu, A., 2014. Managing Entrepreneurship in Higher Education Institutions - Case Romania. MEST Journal, July, 2(2), pp. 1-9.

4. Buchheit, P., 2015. The incredible shrinking middle class: Half of the country is either living in poverty or damn near close to it. Salon, 23 DEcember.

5. Clark, R., Lusardi, A. \& Mitchell, O. S., 2017. Employee financial literacy and retirement plan behavior: a case study. Economic Inquiry, 55(1), p. 248-259.

6. Dencker, J. C., Gruber, M. \& Shah, S. K., 2009. Pre-Entry Knowledge, Learning, and the Survival of New Firms. Organization Science, 20(3), pp. 516537.

7. Dezsi-Benyovski, A., Nagy, A. \& Szabo, T. P., 2014. Entrepreneurship in Romania-Country Report, s.I.: Global Entrepreneurship Monitor.

8. EBA Consumer Trends, 2019. EBA Consumer Trends Report, s.l.: European Banking Authority.

9. Erta, K., Iscenko, Z., Hunt, S. \& Brambley, W., 2013. Applying behavioural economics at the Financial Conduct Authority. London, UK: Financial Conduct Authority. 
10. European Comission, 2020. Unleashing the full potential of European SMEs, s.l.: s.n.

11. European Commission, 2012. Rethinking education: Investing in skills for better socio-economic outcomes, s.l.: s.n.

12. European Commission, 2013. Reigniting the entrepreneurial spirit in Europe.

13. European Commission, 2018. EntreComp: The European Entrepreneurship Competence Framework. Luxembourg: Publications Office of the European Union. 14. European Commission, 2019. Education and Training Monitor 2019 Romania, Luxembourg: Publications Office of the European Union.

15. Eurostat, 2021. Euroindicatiors 54/2021 - 30 April 2021, s.l.: Eurostat.

16. Folta, T. B., Johnson, D. R. \& O'Brien, J., 2006. Uncertainty, irreversibility, and the likelihood of entry: An empirical assessment of the option to defer. Journal of Economic Behavior \& Organization, November, 61(3), pp. 432-452.

17. GEM, 2014. Entrepreneurship in Romania-Country Report, Global entrereneurship Monitor.

18. Heinberg, A. et. al, 2014. Five steps to planning success: experimental evidence from US households. Oxford Review of Economic Policy, 30(4), p. 697724.

19.IFFM,2021.Available at: https://financemuseums.org/ [Accesed 2021].

20. Kraus, S. și alții, 2020. The economics of COVID-19: initial empirical evidence on how family firms in five European countries cope with the corona crisis. International Journal of Entrepreneurial Behavior \& Research, 26(5), pp. 10671092.

21. Lacatus, L. M., 2016. FE in Romania. International Handbook of Financial Literacy, pp. 321-328.

22. Lazear, E. P., 2004. Balanced Skills and Entrepreneurship. American Economic Review, 94(2), pp. 208-211.

23. Lusardi, A., 2014. Financial Literacy: Do People Know the ABCs of Finance?. s.l.:Global Financial Literacy Excellence Center.

24. Lusardi, A., 2019. Financial literacy and the need for FE: evidence and implications. Swiss Journal of Economics and Statistics, Volume 1, p. 155.

25. McNally, J. J., Martin, B. C. \& Kay, M. J., 2013. Examining the formation of human capital in entrepreneurship: A meta-analysis of EE outcomes. Journal of Business Venturing, March, 28(2), pp. 211-224.

26. OECD, 2005. Recommendation on Principles and Good Practices for Financial, Paris: DIRECTORATE FOR FINANCIAL AND ENTERPRISE AFFAIRS.

27. OECD, 2008. EE in Europe, s.I.: European Foundation for Entrepreneurship Research.

28. OECD, 2017. Entrepreneurship at a Glance 2017, Paris: OECD Publishing. 29. OECD, 2017. PISA 2015 results (Volume IV): students' financial literacy, Paris: PISA, OECD Publishing.

30. OECD, 2018. OECD Future of Education and Skills for 2030, Paris: OECD Publishing.

31. OECD, 2019. Society at a Glance 2019: OECD Social Indicators, Paris: OECD Publishing.

32. OECD, 2020. OECD/INFE 2020 International Survey of Adult Financial Literacy, Paris: OECD Publishing.

33. OECD, 2020. PISA 2018 Results ARE STUDENTS SMART ABOUT MONEY? VOLUME IV, Paris: OECD Publishing. 
34. OECD, I. a., 2018. The Application of Behavioural Insights to Financial Literacy and Investor Education Programmes and Initiatives, s.I.: IOSCO and OECD.

35. Oosterbeek, H., van Praag, M. \& ljsselstein, A., 2010. The impact of EE on entrepreneurship skills and motivation. European Economic Review, Volume 48, p. 442-454.

36. Ransome, A., 2014. A father's plea: Why isn't entrepreneurship part of the curriculum?:The Globe and Mail.

37. Ratten, V. \& Jones, P., 2021. Covid-19 and EE: Implications for advancing research and practice. The International Journal of Management Education, 19(1). 38. Ratten, V. \& Jones, P., 2021. Entrepreneurship and management education: Exploring trends and gaps. The International Journal of Management Education.

39. Rinne, R., 2008. The growing supranational impacts of the OECD and the EU on national educatinal policies and the case of Finland. Policy Futures in Education, 6(6), pp. 665-680.

40. Romanian National Bank, 2015. FE...matters!, Minsk: Banca Nationala a Romaniei.

41. Rosendahl Huber, L., Sloof, R. \& Van Praag, M., 2014. The effect of early EE: Evidence from a field experiment. European Economic Review, Volum 72, pp. 7697.

42. Toft-Kehler, R., Wennberg, K. \& Kim, P. H., 2014. Practice Makes Perfect: Entrepreneurial-experience Curves and Venture Performance. Journal of Business Venturing, 29(4), pp. 453-470.

43. Twaalfhoven, B. \& Wilson , K., 2004. Breeding More Gazelles: The Role of European Universities. EFER, Issue October.

44. Unger, J. M., Rauch, A., Frese, M. \& Rosenbusch, N., 2011. Human capital and entrepreneurial success: A meta-analytical review. Journal of Business Venturing, 26(3), pp. 341-358.

45. Urban, C., Schmeiser, M., Collins, M. J. \& Brown, A., 2020. The effects of high school personal FE policies on financial behavior. Economics of Education Review, Volume 78.

46. van der Sluis, J., van Praag, M. \& Vijverberg, W. P., 2008. Education and Entrepreneurship Selection and Performance: A Review of the Empirical Literature. Journal of Economic Surveys, December, 22(5), pp. 795-841.

47. Van Praag, M., Van Witteloostuijn, A. \& Van Der Sluis, J., 2013. The Higher Returns to Formal Education for Entrepreneurs versus Employees. Small Business Economics, 40(2), pp. 375-96.

48. Wagner, J., 2003. Testing Lazear's Jack-of-All-Trades View of Entrepreneurship with German Micro Data. Applied Economics Letters, Volume 10, pp. 687-689. 